\title{
Evaluation of an Educational Program Regarding Cancer Cervix for Health Care Workers in Family Health Facilities
}

\author{
Safa Hamdy Alkalash ${ }^{1 *}$, Osama Ali Al-Kilany ${ }^{2}$, Aml Yahia Shams El-Deen ${ }^{3}$ \\ ${ }^{1}$ Family Medicine Department, Faculty of Medicine - Menoufia University, Egypt. \\ ${ }^{2}$ Gynecology and Obstetrics Department, Faculty of Medicine - Menoufia University, Egypt. \\ ${ }^{3}$ Family Physician, Ministry of Health, Egypt.
}

\begin{abstract}
:
Background: Cervical cancer is second most common women cancer in the world. Screening can reduce incidence and mortality by $80 \%$. Poor knowledge and negative attitude towards cervical cancer screening methods among health care workers can pose substantial barriers to cervical cancer control program in Egypt and developing countries. Objective: was to evaluate the effect of an educational program on knowledge and attitude of health care workers regarding cervical cancer and its screening.
\end{abstract}

Methods: An intervention study (by application of an educational program) was conducted for 333 health care workers in family health facilities in Al Mahalla Al Kobra district, Gharbiya governorate in 2018. An informed written consent was obtained from each participant and a structured questionnaire which included three parts was applied to assess general characteristics of HCWs, knowledge and attitude about cervical cancer. In addition, a health education program was conducted for improving their knowledge and attitude. Post-test was conducted after 3 months for them. Results: About $45 \%$ of HCWs aged between $30-39$ years old with mean \pm SD $(38.51 \pm 8.6)$ there was a highly significant difference between HCWs knowledge and attitude pre and postintervention by the educational program, whereas, $20.1 \%$ of them had a good knowledge score preintervention improved to be $43.5 \%$ post-intervention. Also there was significant improvement in their attitude, as positive attitude pre-intervention was $40.2 \%$ increased to be $94.3 \%$ postintervention.

Conclusion: The present study revealed that applied educational program regarding cancer cervix was successful in enhancing knowledge \& improving attitude of HCWs regarding cervical cancer and its screening.

Keywords: Cervical cancer, Egypt, Health Care Workers, Screening

\section{Introduction:}

Cervical cancer is the second most frequent cancer in women with an estimated 570,000 new cases in 2018 representing $6.6 \%$ of all female cancers. Approximately $90 \%$ of deaths from cervical cancer occurred in lowand middle-income countries. If detected early, cervical cancer is one of the most successfully treatable cancers. ${ }^{(1)}$

In the United States, the cervical cancer death rate declined by more than $50 \%$ over the last 30 years. This is thought to be mainly due to the effectiveness of screening with the Pap test. ${ }^{(2)}$

Egypt has a population of 30.55 millions women ages 15 years and older who are at risk of developing cervical cancer. Current estimates indicate that every year 866 women are diagnosed with cervical cancer and 373 die from the disease. Cervical cancer ranks as the 13th most frequent cancer among women in Egypt and the 10th most frequent 
cancer among women between 15 and 44 years of age. ${ }^{(3)}$

In Egypt about $2.7 \%$ of women in the general population are estimated to harbour cervical HPV-16/18 infection at a given time, and $78.9 \%$ of invasive cervical cancers are attributed to HPVs 16 or $18 .^{(3)}$

Carcinoma of the cervix is a disease of sexually active women and is attributed to infection with specific high-risk strains of human papilloma virus (HPV). Screening has been proven to reduce the incidence and mortality from cervical cancer up to $80 \%$ in developed countries. ${ }^{(2)}$.Regular (PAP) smear screening has reduced the incidence of mortality from cervical cancer, therefore this test is recommended for all sexually active females worldwide. ${ }^{(4)}$

Risk factors for cancer cervix include: earlier onset of sexual activity, multiple partners, cigarette smoking, and immunosuppression. ${ }^{(5)}$ Primary prevention of cervical cancer: is possible through vaccination against HPV and healthy lifestyles such as use of condoms and reduction of sexual partners. ${ }^{(6)}$

Family physicians are well-trained to provide comprehensive care to cancer patients because of their accessibility in the community and their relationships with patients, particularly their knowledge of the personal history, social circumstances, and comorbidities of those patients. ${ }^{(7)}$

The female health care worker plays important roles as a health educator and a promoter. Therefore, unsatisfactory knowledge and low compliance with screening recommendations may lead to negative impact on community in undergoing a Pap smear. ${ }^{(8)}$ The aim of this study was to evaluate the effect of an educational program on knowledge and attitude of health care workers regarding cervical cancer and its screening.

\section{Subject and method:}

Research design: This study was conducted in two phases; First phase was a cross sectional study followed by application of an educational program about cancer cervix and its screening as a second phase of the study. Study Setting and its time: The study was carried out in Gharbiya Governorate which selected by simple random sampling technique. Gharbiya Governorate includes 8 districts. Almahalla Al Kobra district was selected by the same sampling technique during the period from 1st of January 2018 to end of February 2019. From a list of 56 family health facilities distributed in Al Mahalla AlKubra district, a number of 28 family health 
facilities (centers \& units) have been randomly chosen.

Population and sample: Target population were physicians (General practitioner, Family medicine resident, Family medicine specialist and Consultant.), Rural Pioneers Rayeda Rifeya and Nurses including (University\& Secondary education) who provide women health care. On the basis of past review of the literature ${ }^{(9)}$ which found that $58.9 \%$ of the HCWs had adequate knowledge on cervical cancer and total population of (2084) who provide women health care. The sample size had been calculated using the following equation: $\mathrm{N}=(\mathrm{t} 2 \times \mathrm{p}(1-\mathrm{p})) \div \mathrm{m} 2$. Confidence level at $95 \%$ (standard value of 1.96); the sample size was 316 and increased to be 333 health care workers to avoid drop out. The sample size was selected by using simple random sampling technique. There was no drop out.

Study variables: Main study variables were:

- Independent variables included: age, sex, marital status, education level, profession and years of experience.

- Dependent variables included: Knowledge \& Attitude of the participants.

Tools for data collection and procedure: Tools included: A questionnaire and an educational program.

\section{A-Self-administered structured validated} questionnaire was provided for participants who were asked to fill it individually.

The time process for administration of the questionnaire took 20-30 minutes on average and all complete questionnaires were returned directly to the investigators. The questionnaire consisted mainly of close-ended question.

The questionnaire composed of three sections: The first section included socio-demographic information of the participants such as; age, sex, marital status, education level, profession, years of experience and working hours per week. The second section involved questions to detect their knowledge about cervical cancer. The third section was to assess their attitude regarding cancer cervix screening.

The questions which assess the knowledge were 23 questions which scored as follows: $0 \rightarrow$ for wrong answer. $1 \rightarrow$ for right answer. According to Kress et al.,2015 .The overall knowledge score was calculated based on the number of questions answered correctly:

- Good knowledge when total score $\geq 75 \%$.

- An average knowledge when total score 50 $\%: 74 \%$.

- Poor knowledge when total score $<50 \%$. 
The questions which assessed attitude were 14 questions which scored as follows: $0 \rightarrow$ for negative attitude. $1 \rightarrow$ for positive attitude.

According to Ehiemere et al.,2015 (10) the overall attitude score was calculated based on the number of questions answered correctly:

- Positive attitude if total score $\geq 50 \%$.

- Negative attitude if total score $<50 \%$.

Validity of the questionnaire was tested by being submitted to a panel of 3 experts to test its validity .The experts were professors in Family medicine, Community medicine, Obstetrics / Gynecology medicine.

The preliminary items were revised by the experts to determine whether the items were relevant for assessment. The expert were asked to evaluate individual items in relation to its relevance and appropriateness then rate items on a 4 point scale as the following:

4 Adequate (simple, relevant \&clear)

3 Adequate but needs minor revision.

2 Needs major modification.

1 Not so adequate( could be omitted) Content validity index (CVI) :Percentage of total item rated by experts as either 3or 4.the score of $\geq 80 \%$ is generally considered to have a good validity Scilling et al., 2007. ${ }^{(11)}$ CVI of the designed questionnaire was calculated and it was $95 \%$.
Reliability of the questionnaire was calculated by SPSS version 20 using Cronbach's alpha which was $(\mathrm{r}=0.8)$.Hence the questionnaire is reliable.

B- An educational program aimed to improve the health care workers knowledge and attitude regarding cervical cancer and its screening.

Main items of the program were: definition, prevalence, risk factors, etiology and early signs of cancer cervix. Also it involved evidence about role of cancer cervix screening in early detection of cancer cervix, age to begin, year's interval and when to stop screening, role of health workers in early detection and referral of suspected woman also their role in rising community awareness regarding importance of cancer cervix screening. The educational program was designed by reviewing different evidence based sources as (Funston et al., 2018), (12) (Australian institute of health and welfare, 2018) ${ }^{(13)} \&$ (Rifai \& Loney,2017). ${ }^{(3)}$

Methods of teaching were lectures, group discussion and demonstration with use of visual aids. It includes: Booklet \& Colored posters.

- A pilot study was undergone in context of time frame one month before beginning of the study through which the study was 
conducted for 30 health care providers in the setting of the study and through this pilot study the questionnaire was pretested and time needed for completing its filling was determined, also educational program applied and assessed regarding educational material, its duration and place of its implementation.

Procedure of the study: Health care providers who included in the study were first interviewed by the researcher and their knowledge and attitude towards cervical cancer and its screening were assessed through filling previously designed questionnaire. Then, HCWs gathered by end of the day in family health club and the educational program was applied for them in groups. Each group included nearly 5 to 10 HCWs and takes nearly 60 minutes.

- Evaluation of the program:

Three months later, posttest was applied for the participants to evaluate their knowledge\& attitude using the same pretest questionnaire and evaluated according to the same method of scoring that was used before application of the program.

Data management: Statistical presentation and analysis of the present study was conducted with SPSS V. 20. Data was expressed into two phases:

\section{I- Descriptive:}

1- Mean value and standard deviation [SD]: For quantitative data.

2- Frequency and percentage for qualitative data. Figure (Pie chart) was designed by using Microsoft excel 2010

II- Analytic: which include the following tests:

- Chi- square test $\left(\chi^{2}\right)$ : for comparison between independent categorical (qualitative) variables normally distributed.

- MC Nemar test: for paired nominal data (dichotomous) dependent variable.

$\mathrm{P}$ value $<0.05$ was considered statistically significant.

$\mathrm{P}$ value $<0.001$ was considered statistically highly significant.

Ethical considerations: In accordance with the Declaration of Helsinki, the study was approved by the ethical committee of the faculty of medicine, Menoufia University. An official permission letter was obtained from the authorities and directed to health administration in Al-Mahalla Al-Kobra district. All participants were volunteers. An informed written consent was taken from each health care worker in the selected family 
health facilities after complete explanation of the purpose of this study and assuring confidentiality.

\section{Results:}

The mean age of the studied group was (38.51 \pm 8.6$)$ years old, ranging from 21 to 58 years. About three quarters of the participants were females $(75.4 \%)$. The majority of the participants were married (88.6\%). About half of the participants were secondary educated $(56.5 \%)$. Mean of experience years of the studied group was (16.87 \pm 9.6$)$, with the majority $(71.5 \%)$ had work experience years $>10$ years. lastly mean of working hours / week was (37.84 \pm 5.4$)$ (Table 1).

The present study showed that the major source of information regarding cervical cancer screening were: Previous background from college education (31.2\%), From attending training courses (15.6\%), Internet $(13.5 \%)$, reading books (12.6\%), then lastly mixed source of information (27.0\%) (Figure1).

There were remarkable improvement in participant's levels of knowledge about cancer cervix (etiology, risk factors, prevalence and screening) after application of educational program in comparison to before application of the program $(\mathrm{P}<0.001)$, as knowledge regarding etiology increased from $26.4 \%$ to $48.0 \%$. Knowledge regarding risk factors increased from $15.0 \%$ to $39.6 \%$. Knowledge regarding prevalence increased from $40.2 \%$ to $53.8 \%$. Knowledge regarding screening increased from $24.3 \%$ to $64.9 \%$. Overall good and average knowledge scores pre-intervention were $20.1 \% \& 30.9 \%$ while post-intervention increased to $43.5 \%$ \& $32.7 \%$ respectively (Table 2).

There was a highly statistically significant difference between attitude of the studied group about screening of cancer cervix pre and post intervention by the educational program. Positive attitude preintervention $40.2 \%$ increased to $94.3 \%$ post intervention $(\mathrm{P}<0.001)$ (Table 3).

Overall knowledge score was highly significantly affected by their job $(\mathrm{P}<0.001)$, being poor among Raeda Rifeya (73.8\%) and good among Family medicine consultants (83.3\%). Knowledge score among HCWs was highly statistically significantly affected by age and experience years $(\mathrm{P}<0.001)$, being higher (46.9\%) among younger participants $<30$ years old and HCWs with experience years $\leq 5$ years $(63.9 \%)$. In relation to gender, social status and education : Knowledge was statistically significant higher among un married (44.7\%), men (63.9 \%) and HCWs 
with postgraduate education $(68.3 \%) \quad(\mathrm{P}$ $<0.001)$ (Table4).

There were highly statistical significant differences in attitude of the studied group in relation to age, experience years, job \& education level $(\mathrm{P}<0.001)$ as positive attitude was higher among younger age HCWs, who have experience years less than five years , family physician doctors (resident \& consultant) and highly educated HCWs. There was a statistical significant difference in attitude among the studied group as regards their marital status (P Value was 0.002) (Table 5).

\section{Discussion:}

This study aimed to assess effect of an educational program on knowledge and attitude of health care workers regarding cervical cancer and its screening. Regarding personal characteristics of the studied group, in this study majority of the respondents were midwives (38.4\%) and nurses (17.4\%). It agreed with a Nigerian study was done by Ehiemere et al., 2015 which revealed that majority of the respondents were nurses $(66.5 \%)^{(10)}$. Similarity of both results may be due to increased number of nursing in health facilities in general. The current study revealed that female sex was more than three quarters of the participants $(75.4 \%)$. This finding agreed with results of studies were done in Kenya by Kieti, 2016 and in Ethiopia by Kress et al., 2015 which reported that majority of the nurses were females $(86 \%$ \& $65 \%)$ respectively .This is because nursing profession is occupied by women more than men all over the world ${ }^{(14)(9)}$.

Regarding Source of information about cervical cancer and its screening, the present study showed that the major sources of information regarding cervical cancer screening were: Previous background from college education (31.2\%), from attending training courses on screening $(15.6 \%)$, Internet $(13.5 \%)$, reading books $(12.6 \%)$, and then lastly mixed source of information $(27.0 \%)$.

The result agreed with results of a study conducted in Nigeria by Biobaku et al., 2015 which revealed that majority of the respondents $(73.8 \% ; 71.4 \%)$ detailed formal lectures during training and seminars respectively. Other sources of information were work exposure $(70.0 \%)$, reading medical books (69.0\%) media (55.7\%) and the internet $(48.1 \%)^{(15)}$

It also agreed with a study conducted in India by Kosambiya et al., 2018 which concluded that major source of information for cervical cancer among female health care 
workers were research related to nursing $(96 \%)^{(16)}$

The results disagreed with a study conducted by Mali\& Mali, 2014 in India which reported that $(63.6 \%)$ of the participants gain their information from work experience $^{(17)}$. It was also in controversy with results of a study that was conducted in India by Pegu et al., 2017which revealed that majority $(73.5 \%)$ of respondents got their information from media followed by from books $(11.8 \%){ }^{(18)}$

It also disagreed with a study conducted in Hong Kong by Chiang et al., 2016 who found that the main source of information was television (around 75\%), followed by the internet and newspapers /magazines (all slightly more than $40 \%)^{(19)}$

Regarding comparison between knowledge score of the participants before and after application of educational program, The current study showed that there were remarkable improvement in participant's levels of knowledge about cancer cervix (etiology, risk factors, prevalence and screening) after application of educational session in comparison to pre-application of the session. This result approximated findings were reported by Abo-Lela et al., 2017 in Egypt which revealed that there was significant improvement of nurse's knowledge about cervical cancer whereas their knowledge improved from $21.8 \%$ pre intervention to $91.8 \%$ post intervention. ${ }^{(20)}$

Also this result was in line with results of an Indian study conducted by Poonam et al., 2012 on nursing students who found that nearly a quarter of nurses were aware of symptoms of cervical cancer in pretest are significantly improved in post-test. ${ }^{(21)}$

The current study also agreed with studies conducted by Biobaku et al., 2015 \& Mali, 2014 which were performed in Nigeria \& India respectively and reported that majority of studied group had poor knowledge about cervical cancer in pre intervention $(58 \%) \&(20 \%)$ respectively and the knowledge was relatively better and the scores were also improved in post-intervention $(98.9 \%) \&(51.2 \%)$ respectively. ${ }^{(15)(17)}$

Regarding comparison between attitude of the participants before and after application of educational session, Positive attitude regarding screening of cancer cervix was significantly improved after application of educational program. Positive attitude before session $(77.8 \%)$ increased to be $(94.3 \%)$ after the session. This result was in line with a study conducted in Kerala by Mary \& Kundapur , 2018 which revealed that there 
was significant difference of attitude score before and after teaching program as $14 \%$ have moderate attitude, $42 \%$ have good attitude before application of teaching program whereas $30 \%$ have moderate attitude and $70 \%$ have good attitude after the program (22). Also it was supported by results of an Egyptian study conducted by Said et al., 2018 which stated that $0.0 \%$ of the studied women have positive attitude to pre intervention meanwhile, after intervention $30.8 \%$ of them have positive attitude. ${ }^{(23)}$

Regarding relationship between knowledge and personal characteristics, current study showed that knowledge score among HCWs was highly statistically significantly affected by age and experience years, being higher among younger participants $<30$ years old and HCWs with experience years $\leq 5$ years.

This result was in agreement with result which was reported by Ramathuba \& Ngambi, 2018 in South Africa which showed that knowledge about cervical cancer is fairly and negatively related to the age range of respondents. As the age range increased, the knowledge about cervical cancer decreased. ${ }^{(24)}$

The current study revealed that the level of overall knowledge score of studied group is highly significantly affected by their job $(\mathrm{P}<0.001)$ being poor among raeda rifeya and midwifes $(73.8 \% \& 66.4 \%)$ respectively and well among family medicine consultants (83.3\%). This result was in line with a study done by Sudharshini et al., 2013 on female HCWs in India and showed that knowledge about cervical cancer screening was good among medical officers and sector health nurses than other professions. This could be because of their educational status and the long duration of service in the health system. (23)

Limitations of the study: The KA survey was conducted among health service workers of some family health facilities hence, the findings do not reflect the level of knowledge, and attitudes of health service workers working in other health institutions. Some HCWs refused to participate in the study. Others were so busy to have time to fill the questionnaire. There wasn't suitable place for the educational session in some units. majority of $\mathrm{HCWs}$ refused to attend the session as they were so busy to have an hour during work time, it was overcame through making each session included nearly 5 to 10 HCWs who were not busy at the time of the session in order to facilitate their attendance to the sessions and to achieve their work duties. 
Conclusion: The present study revealed that applied educational program regarding cancer cervix was successful in enhancing knowledge \& improving attitude of $\mathrm{HCWs}$ regarding cervical cancer and its screening. So we recommend continuous educational training programs for nurses and medical students to increase their awareness about cervical cancer.

\section{Acknowledgements:}

Researchers would like to express great and deep gratitude and sincere appreciation to all participants who agree to participate in this study.

Fund: No fund was received.

Conflict of interest: There is no conflict of interest.

\section{References:}

1. Bray F, Ferlay J, Soerjomataram I, Siegel R, Torre L \& Jemal A: Global cancer statistics 2018: GLOBOCAN estimates of incidence and mortality worldwide for 36 cancers in 185 countries. CA: A Cancer Journal for Clinicians, 2018: 68 (6) : 394-424.

2. Schlichte J, \& Guidry $\mathbf{J}$ : Current Cervical Carcinoma Screening Guidelines. Multidisciplinary Digital Publishing Institute, Journal of clinical medicine, 2015; 4(5): 918-932.
3. Al-Rifai $\mathbf{R} \&$ Loney $\mathbf{T}$ : Factors Associated with a Lack of Knowledge of Performing Breast Self-Examination and Unawareness of Cervical Cancer Screening Services: Evidence from the, Egypt Health Issues Survey, Asian Pacific journal of cancer prevention: APJCP, 2017; 18 (10): 2763-2769.

4. Arbyn M, Anttila A, Jordan J, Ronco G, Schenck U, Segnan N., et al.,: European guidelines for quality assurance in cervical cancer screening, European Union, Second edition, 2010 ; 21(3): 448458.

5. Kimani F, Sharif S \& Bashir I: Ministry of Public Health and Sanitation and Ministry of Medical Services National Cervical Cancer Prevention Program in Kenya: Strategic Plan 2012-2015. Nairobi, Kenya, 2012 . p:23.

6. Crowe E, Pandeya N, Brotherton M, Dobson J, Kisely S,Lambert S et al. : Effectiveness of quadrivalent human papillomavirus vaccine for the prevention of cervical abnormalities case-control study nested within a population based screening programme in Australia. BMJ, 2014 : 348, : 1458-1458

7. Easley J, Miedema B, Brien O, Carroll J, Manca D, Webster F, et al.: The role 
of family physicians in cancer care: perspectives of primary and specialty care workers, Current oncology (Toronto, Ont.) $2017: 24$ (2): 75-80.

8. Sudharshini S, Anantharaman V \& Chitra A: A cross-sectional study on knowledge, attitude, and practice on cervical cancer and screening among female health care workers of Chennai corporation,. Journal of Academy of Medical Sciences, $2012: 2$ (4) : 124-128.

9. Kress C, Sharling L, Owen-smith A, Desalegn D, Blumberg M, \& Goedken J: Knowledge, attitudes, and practices regarding cervical cancer and screening among Ethiopian health care workers. International Journal of Women's Health, 2015: 7: 765-772.

10. Ehiemere O, Maureen F \& RobinsonBassey G: Attitude and practice of cervical cancer screening among female health workers in university of PortHarcourt teaching hospital, Rivers State, Journal of Research in Nursing and Midwifery, Department of Nursing, Faculty of Health Sciences and Technology, University of Nigeria, Enugu Campus, Nigeria, 2015: 4 (5) : 72-82.

11. Schilling LS, Diaxon JK, Knafl KA, Grey M, Ives B, et al., (2007):
Determining content validity of a selfreport instrument for adolescents using a heterogonous expert panel. Nurs Res. 2007 ; $56(5): 361-6$.

12. Funston G, O'Flynn H, Ryan J, Hamilton W \& Crosbie J (2018): recognizing Gynecological Cancer in Primary Care: Risk Factors, Red Flags, and Referrals. Advances in Therapy, 2018 vol: 35 (4) pp: 577-589.

13. Australian Institute of Health and Welfare (2018): Cervical screening in Australia 2018, Canberra.

14. Kieti S : Knowledge, attitude and practices on cervical cancer screening and prevention methods among nurses at two Nairobi hospitals in Kenya, submitted in accordance with the requirements for the degree of master of arts in nursing science at the university of south Africa, 2016 .p:41.

15. Biobaku O, Adesegun O, Fatusi P \& Afolabi B: Perception, Sources of Information and Utilization of Papanicolaou (PAP) Smear for Cervical Cancer screening among Female Nurses in Southwest Nigeria. Part 1. Journal Of Prevention \& Infection Control, $2015: 1$ (1) 5 . 
16. Kosambiya R, Gohil A, Kamdar Z, Patel P \& Modi A: Knowledge, Attitude and Practices about Cervical Cancer and Screening among Nurses of a Tertiary Care Centre in Western India, National Journal of Community Medicine, 2018: 9 (6): 391-395.

17. Mali N \& Mali R: Effect of Structured Education on Knowledge Regarding Prevention of Cervical Cancer among A.N.M. Students. International Journal of Science and Research.(JISR), 2014 :3 (3) 2319-7064.

18. Chiang V, Wong H, Yeung P, Choi Y, Fok M, Mak $O$ et al., : Attitude, Acceptability and Knowledge of HPV Vaccination among Local University Students in Hong Kong. International journal of environmental research and public health, 2016: 13 (5).

19. Pegu B, Dhiman N, Chaturvedi J \& Sharma S: Nurse's knowledge and attitude regarding cervical cancer screening at a tertiary care hospital. International Journal of Reproduction, Contraception, Obstetrics and Gynecology, 2017: 6 (3): 907.

20. Abo-Lela H, Mansour S, Barakat R \& Khedr N: Effect of Applying Educational Sessions on the Nurses' Knowledge regarding Cervical Cancer. (IOSR) Journal of Nursing and Health Science (IOSR-JNHS) 2017: 6 (4) : 29-36.

21. Poonam N, Nagaraj $K$ \& Nirgude A : Awareness of Cervical Cancer Risk Factors and Screening Behaviour among Nurses in a Rural Region of Turkey.Asian(Andhra Pradesh). Pacific J Cancer Prev 2012; 10: 735.

22. Mary J \& Kundapur R: Effect of Video Assisted Education on Cervical Cancer on Learning outcomes among Married Women in a Selected Anganwadies under Mundur Phc, Palakkad-Kerala. Archives of Immunology and Allergy V1 . .2018; 1, 8-17.

23. Said S, Hassan H \& Sarhan A: Effect of an Educational Intervention on Women's Knowledge and Attitude Regarding Cervical Cancer. American Journal of Nursing Research, 2018 : 6 (2) : 59-66.

24. Ramathuba D \&Ngambi D: Knowledge and Attitudes of Women towards Human Papilloma Virus and HPV Vaccine in Thulamela Municipality of Vhembe District in Limpopo Province, South Africa. African journal of reproductive health, 2018 ; 22 (3) : 111-119. 
Table (1): Socio-demographic data of the participants

\begin{tabular}{|c|c|c|}
\hline Item & Frequency $N=333$ & Percentage \% \\
\hline \multirow{4}{*}{$\begin{aligned} \text { Age }: & \\
& -<30 \\
& -30-39 \\
& -\geq 40\end{aligned}$} & \multicolumn{2}{|r|}{$(38.51 \pm 8.595)$} \\
\hline & 49 & $14.7 \%$ \\
\hline & 149 & $44.7 \%$ \\
\hline & 135 & $40.5 \%$ \\
\hline \multicolumn{3}{|l|}{ Sex } \\
\hline $\begin{array}{l}\text { - Male } \\
\text { - Female }\end{array}$ & $\begin{array}{c}72 \\
261\end{array}$ & $\begin{array}{l}21.6 \% \\
78.4 \%\end{array}$ \\
\hline \multicolumn{3}{|l|}{ Education level } \\
\hline - secondary & 188 & $56.5 \%$ \\
\hline - University & 104 & $31.2 \%$ \\
\hline - postgraduate & 41 & $13.3 \%$ \\
\hline \multicolumn{3}{|l|}{ Marital status } \\
\hline - Single & 38 & $11.4 \%$ \\
\hline - Married & 295 & $88.6 \%$ \\
\hline \multicolumn{3}{|l|}{ Profession } \\
\hline \multirow{7}{*}{$\begin{array}{ll}\text { - } & \text { Raeda ryfya } \\
\text { - } & \text { Midwife } \\
\text { - } & \text { Nurse } \\
\text { - } & \text { GP } \\
\text { - } & \text { FP resident } \\
\text { - FP specialist } \\
\text { - }\end{array}$} & 61 & $18.3 \%$ \\
\hline & $\begin{array}{c}128 \\
58\end{array}$ & $38.4 \%$ \\
\hline & 58 & $17.4 \%$ \\
\hline & 9 & $2.7 \%$ \\
\hline & 30 & $9.0 \%$ \\
\hline & 35 & $10.5 \%$ \\
\hline & 12 & $3.6 \%$ \\
\hline \multirow{4}{*}{$\begin{array}{c}\text { Experience years } \\
\qquad \quad \leq 5 \text { years } \\
\bullet \quad 6-10 \text { years } \\
\bullet \quad>10 \text { years }\end{array}$} & \multicolumn{2}{|c|}{$16.87 \pm 9.59$} \\
\hline & 36 & $10.8 \%$ \\
\hline & 59 & $17.7 \%$ \\
\hline & 238 & $71.5 \%$ \\
\hline Working hours / week & \multicolumn{2}{|c|}{$\mathbf{3 7 . 8 4} \pm \mathbf{5 . 3 7}$} \\
\hline
\end{tabular}


Table (2): Comparison between knowledge of the participants before and after application of educational program

\begin{tabular}{|c|c|c|c|c|c|c|}
\hline Overall & \multicolumn{2}{|c|}{ Pre-test } & \multicolumn{2}{|c|}{ Post-test } & $\mathbf{X}^{2}$ & P value \\
\hline & $\mathbf{N . 3 3 3}$ & $\%$ & N. 333 & $\%$ & \multirow[t]{4}{*}{$\mathbf{5 8 . 2 5}$} & \multirow[t]{4}{*}{$<0.001 * *$} \\
\hline Good & 67 & $20.1 \%$ & 145 & $43.5 \%$ & & \\
\hline Average & 103 & $30.9 \%$ & 109 & $32.7 \%$ & & \\
\hline Poor & 163 & $48.9 \%$ & 79 & $23.7 \%$ & & \\
\hline \multicolumn{5}{|c|}{ knowledge Score regarding etiology } & \multirow[t]{4}{*}{141.55} & \multirow[t]{4}{*}{$<0.001 * *$} \\
\hline Good & 89 & $26.4 \%$ & 160 & $48.0 \%$ & & \\
\hline Average & 62 & $18.4 \%$ & 135 & $40.5 \%$ & & \\
\hline Poor & 182 & $54.0 \%$ & 38 & $11.4 \%$ & & \\
\hline \multicolumn{5}{|c|}{ knowledge Score regarding risk factors } & \multirow[t]{4}{*}{214.02} & \multirow[t]{4}{*}{$<0.001 * *$} \\
\hline Good & 50 & $15.0 \%$ & 132 & $39.6 \%$ & & \\
\hline Average & 73 & $21.9 \%$ & 172 & $51.7 \%$ & & \\
\hline Poor & 210 & $63.1 \%$ & 29 & $39.6 \%$ & & \\
\hline \multicolumn{5}{|c|}{ knowledge Score regarding prevalence } & \multirow[t]{4}{*}{73.59} & \multirow[t]{4}{*}{$<0.001 * *$} \\
\hline Good & 134 & $40.2 \%$ & 179 & $53.8 \%$ & & \\
\hline Average & 71 & $21.3 \%$ & 120 & $36.0 \%$ & & \\
\hline Poor & 128 & $38.4 \%$ & 34 & $10.2 \%$ & & \\
\hline \multicolumn{5}{|c|}{ knowledge Score regarding screening } & \multirow[t]{4}{*}{202.58} & \multirow[t]{4}{*}{$<0.001 *$} \\
\hline Good & 82 & $24.3 \%$ & 216 & $64.9 \%$ & & \\
\hline Average & 58 & $17.2 \%$ & 94 & $28.2 \%$ & & \\
\hline Poor & 193 & $57.3 \%$ & 23 & $6.9 \%$ & & \\
\hline
\end{tabular}

**Highly statistically significant. 
Table (3): Comparison between attitude of the participants before and after application of educational program

\begin{tabular}{|l|l|l|l|l|l|l|}
\hline Attitude Score & \multicolumn{2}{|l|}{ Pre-intervention } & \multicolumn{2}{l|}{$\begin{array}{l}\text { Post- } \\
\text { intervention }\end{array}$} & $\begin{array}{l}\text { MC Nemar } \\
\text { Test }\end{array}$ & P value \\
\hline & N. & $\%$ & N & $\%$ & & \\
\cline { 1 - 5 } Positive & 134 & $40.2 \%$ & 314 & $94.3 \%$ & \multirow{2}{*}{----- } & $<0.001^{* *}$ \\
\cline { 1 - 7 } Negative & 199 & $59.8 \%$ & 19 & $5.7 \%$ & & \\
\hline
\end{tabular}

** Highly statistical significant

\section{Source of information}

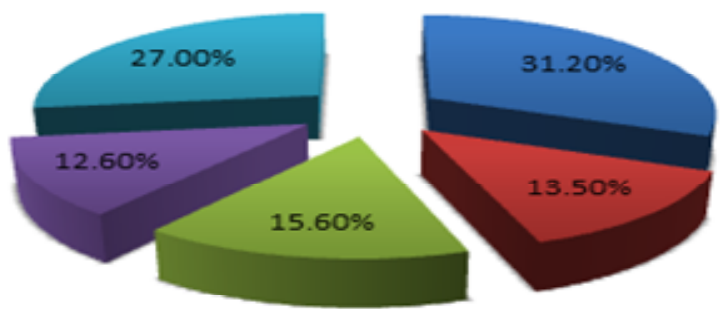

$$
\begin{aligned}
& \text { E Previous background } \\
& \text { Eternet } \\
& \text { E Attending training courses } \\
& \text { Eeading books } \\
& \text { - Mixed source of inform ation }
\end{aligned}
$$

Figure (1): Shows Source of information about cervical cancer screening 
Table (4): Relation between overall knowledge score and some personal characteristics of the participants before application the program

\begin{tabular}{|c|c|c|c|c|c|c|c|c|c|c|}
\hline \multirow{3}{*}{\begin{tabular}{|l|} 
\\
Job :
\end{tabular}} & \multicolumn{2}{|c|}{ Poor K score } & \multicolumn{2}{|c|}{$\begin{array}{c}\text { Average K } \\
\text { score }\end{array}$} & \multicolumn{2}{|c|}{$\begin{array}{c}\text { Good K } \\
\text { score }\end{array}$} & \multicolumn{2}{|c|}{ Total } & \multirow[t]{2}{*}{$\mathbf{X}^{2}$} & \multirow[t]{2}{*}{ P value } \\
\hline & \multicolumn{2}{|c|}{$\mathrm{N}=163$} & \multicolumn{2}{|c|}{$\mathrm{N}=103$} & \multicolumn{2}{|c|}{$\mathrm{N}=67 \quad \%$} & \multicolumn{2}{|c|}{$\mathrm{N}=333 \%$} & & \\
\hline & 45 & $73.8 \%$ & 16 & $26.2 \%$ & 0 & $0.0 \%$ & 61 & $18.3 \%$ & \multirow[t]{7}{*}{222.6} & \multirow[t]{7}{*}{$<0.001 * *$} \\
\hline \multirow{6}{*}{$\begin{array}{l}\text { - Midwife } \\
\text { - Nurse } \\
\text { - GP } \\
\text { - FM resident } \\
\text { - FM specialty } \\
\text { - Consultant }\end{array}$} & 85 & $66.4 \%$ & 38 & $29.7 \%$ & 5 & $3.9 \%$ & 128 & $38.4 \%$ & & \\
\hline & 33 & $56.9 \%$ & 25 & $43.1 \%$ & 0 & $0.0 \%$ & 58 & $17.4 \%$ & & \\
\hline & 0 & $0.0 \%$ & 2 & $22.2 \%$ & 7 & $77.8 \%$ & 9 & $2.7 \%$ & & \\
\hline & 0 & $0.0 \%$ & 7 & $23.3 \%$ & 23 & $76.7 \%$ & 30 & $9.0 \%$ & & \\
\hline & 0 & $0.0 \%$ & 13 & $37.1 \%$ & 22 & $62.9 \%$ & 35 & $10.5 \%$ & & \\
\hline & 0 & $0.0 \%$ & 2 & $16.7 \%$ & 10 & $83.3 \%$ & 12 & $3.6 \%$ & & \\
\hline \multirow{3}{*}{$\begin{array}{l}\text { Age group: } \\
\text { - } \quad<30 \\
\text { - } 30-39 \\
\text { - } \geq 40\end{array}$} & 13 & $26.5 \%$ & 13 & $26.5 \%$ & 23 & $46.9 \%$ & 49 & $14.7 \%$ & \multirow[t]{3}{*}{32.5} & \multirow[t]{3}{*}{$<0.001 * *$} \\
\hline & 70 & $46.9 \%$ & 49 & $32.9 \%$ & 30 & $20.1 \%$ & 149 & $44.7 \%$ & & \\
\hline & 80 & $59.3 \%$ & 41 & $30.4 \%$ & 14 & $10.4 \%$ & 135 & $40.5 \%$ & & \\
\hline \multirow{3}{*}{$\begin{array}{l}\text { Exp. years } \\
\bullet \leq 5 \text { years } \\
\text { - } 6 \text { to } 10 \text { years } \\
\bullet>10 \text { years }\end{array}$} & 4 & $11.1 \%$ & 9 & $25 \%$ & 23 & $63.9 \%$ & 36 & $10.8 \%$ & \multirow[t]{3}{*}{68.9} & \multirow[t]{3}{*}{$<0.001^{* *}$} \\
\hline & 19 & $32.2 \%$ & 21 & $35.6 \%$ & 19 & $32.2 \%$ & 59 & $17.7 \%$ & & \\
\hline & 140 & $58.8 \%$ & 73 & $30.7 \%$ & 25 & $10.5 \%$ & 238 & $71.5 \%$ & & \\
\hline \multirow{2}{*}{$\begin{array}{l}\text { Social status } \\
\text { - Married } \\
\text { - Unmarried }\end{array}$} & 154 & $52.2 \%$ & 91 & $30.8 \%$ & 50 & $16.9 \%$ & 295 & $88.6 \%$ & \multirow[t]{2}{*}{18.5} & \multirow[t]{2}{*}{$<0.001^{* *}$} \\
\hline & 9 & $23.7 \%$ & 12 & $31.6 \%$ & 17 & $44.7 \%$ & 38 & $11.4 \%$ & & \\
\hline \multirow{2}{*}{$\begin{array}{l}\text { Gender } \\
\text { - Men } \\
\text { - Women } \\
\end{array}$} & 5 & $6.9 \%$ & 21 & $29.2 \%$ & 46 & $63.9 \%$ & 72 & $21.6 \%$ & \multirow[t]{2}{*}{124.1} & \multirow[t]{2}{*}{$<0.001 * *$} \\
\hline & 158 & $60.5 \%$ & 82 & $31.4 \%$ & 21 & $8.1 \%$ & 261 & $78.4 \%$ & & \\
\hline \multirow{3}{*}{$\begin{array}{l}\text { Education } \\
\text {-Secondary } \\
\text {-University } \\
\text {-Postgraduate }\end{array}$} & 129 & $68.6 \%$ & 54 & $28.7 \%$ & 5 & $2.7 \%$ & 188 & $56.5 \%$ & \multirow[t]{3}{*}{124.3} & \multirow[t]{3}{*}{$<0.001^{* *}$} \\
\hline & 33 & $31.7 \%$ & 37 & $35.6 \%$ & 34 & $32.7 \%$ & 104 & $31.2 \%$ & & \\
\hline & 1 & $2.4 \%$ & 12 & $29.3 \%$ & 28 & $68.3 \%$ & 41 & $13.3 \%$ & & \\
\hline
\end{tabular}

**Highly statistically significant. 
Table (5): Relation between attitude toward screening of cancer cervix and some characteristics of the participants before application the program

\begin{tabular}{|c|c|c|c|c|c|c|c|c|}
\hline \multirow{2}{*}{ Score } & \multirow{2}{*}{\multicolumn{2}{|c|}{$\begin{array}{l}\text { Positive } \\
(\mathrm{N}=134)\end{array}$}} & \multirow{2}{*}{\multicolumn{2}{|c|}{$\begin{array}{l}\text { Negative } \\
(\mathrm{N}=199)\end{array}$}} & \multicolumn{2}{|c|}{ Total } & \multirow{2}{*}{$\mathbf{X} 2$} & \multirow{2}{*}{$P$ value } \\
\hline & & & & & $\mathbf{N}=3$ & $\%$ & & \\
\hline \multirow{3}{*}{$\begin{array}{l}\text { Gender } \\
\text { - Men } \\
\text { - Women }\end{array}$} & 57 & $79.2 \%$ & & $20.8 \%$ & 72 & $21.6 \%$ & \multirow{3}{*}{56} & \multirow[t]{3}{*}{$<0.001 * *$} \\
\hline & & & 15 & & & & & \\
\hline & 78 & $29.9 \%$ & 183 & $70.1 \%$ & 261 & $78.4 \%$ & & \\
\hline \multirow{3}{*}{$\begin{array}{l}\text { Age group: } \\
\text { - }<30 \\
\text { - } 30-39 \\
\text { - } \geq 40\end{array}$} & 32 & $65.3 \%$ & 17 & $34.7 \%$ & 49 & $14.7 \%$ & \multirow[t]{3}{*}{29.1} & \multirow[t]{3}{*}{$<0.001 * *$} \\
\hline & 69 & $46.3 \%$ & 80 & $53.7 \%$ & 149 & $44.7 \%$ & & \\
\hline & 33 & $24.4 \%$ & 102 & $75.6 \%$ & 135 & $40.5 \%$ & & \\
\hline \multirow{3}{*}{$\begin{array}{l}\text { Experience years: } \\
-\leq 5 \\
\bullet 6-10 \\
\bullet>10\end{array}$} & 28 & $77.8 \%$ & 8 & $22.2 \%$ & 36 & $10.8 \%$ & \multirow[t]{3}{*}{32.3} & \multirow[t]{3}{*}{$<0.001 * *$} \\
\hline & 31 & $52.5 \%$ & 28 & $47.5 \%$ & 59 & $17.7 \%$ & & \\
\hline & 75 & $31.5 \%$ & 163 & $68.5 \%$ & 238 & $71.5 \%$ & & \\
\hline \multirow{8}{*}{$\begin{array}{l}\text { Job : } \\
\text { - Raeda Rifeya } \\
\text { - Midwife } \\
\text { - Nurse } \\
\text { - GP } \\
\text { - FM resident } \\
\text { - FM specialty } \\
\text { - Consultant }\end{array}$} & 26 & $42.6 \%$ & 35 & $57.4 \%$ & & $18.3 \%$ & \multirow[t]{8}{*}{120.8} & \multirow[t]{8}{*}{$<0.001 * *$} \\
\hline & & & & & 61 & & & \\
\hline & 13 & $10.2 \%$ & 115 & $89.8 \%$ & 128 & $38.4 \%$ & & \\
\hline & 22 & $37.9 \%$ & 36 & $62.1 \%$ & 58 & $17.4 \%$ & & \\
\hline & 7 & $77.8 \%$ & 2 & $22.2 \%$ & 9 & $2.7 \%$ & & \\
\hline & 27 & $90.0 \%$ & 3 & $10.0 \%$ & 30 & $9.0 \%$ & & \\
\hline & 28 & $80.0 \%$ & 7 & $20.0 \%$ & 35 & $10.5 \%$ & & \\
\hline & 11 & $91.7 \%$ & 1 & $8.3 \%$ & 12 & $3.6 \%$ & & \\
\hline \multirow{2}{*}{$\begin{array}{l}\text { Social status } \\
\text { - Married } \\
\text { - Unmarried }\end{array}$} & 110 & $37.3 \%$ & 185 & $62.7 \%$ & 295 & $88.6 \%$ & \multirow[t]{2}{*}{9.4} & \multirow[t]{2}{*}{$0.002^{*}$} \\
\hline & 24 & $63.2 \%$ & 14 & $36.8 \%$ & 38 & $11.4 \%$ & & \\
\hline \multirow{3}{*}{$\begin{array}{l}\text { Education } \\
\text { - Secondary } \\
\text { - University } \\
\text { - Postgraduate }\end{array}$} & 39 & $20.7 \%$ & 149 & $79.3 \%$ & 188 & $56.5 \%$ & \multirow[t]{3}{*}{77.6} & \multirow[t]{3}{*}{$<0.001 * *$} \\
\hline & 60 & $57.7 \%$ & 44 & $42.3 \%$ & 104 & $31.2 \%$ & & \\
\hline & 35 & $85.4 \%$ & 6 & $14.6 \%$ & 41 & $13.3 \%$ & & \\
\hline
\end{tabular}

* Statistically significant. 


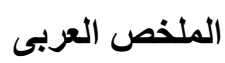

تقييم برنامج تعليمي بشأن سرطان عنق الرحم للعاملين في مجال الرعاية الصحية في مرافق صحة الأسرة

صفا حمدي القلش, أسامة علي الكيلاني , أمل يحيى شمس الدين

الخلفية: سرطان عنق الرحم هو ثاني أكثر أنواع سرطان النساء شيوعًا في العالم. يمكن للفحص أن يقلل من نسبة الإصابة والوفيات بنسبة 80 ٪. يمكن أن يشكل ضعف المعرفة و الموقف السلبي تجاه طرق الكثف عن سرطان عنق الرحم بين العاملين في مجال الرعاية الصحية حو اجز كبيرة أمام برنامج مكافحة سرطان عنق الرحم في مصر والبلدان النامية.

الهذف: تم تقييم تأثثر برنـامج نعليمي على معرفة وموقف العاملين في مجـال الرعايـة الصحية فيما يتعلق بسرطان عنق الرحم وفحصد.

المشاركين وطرق البحث : أجريت در اسـة تدخلية للعـلين في مجـال الرعايـة الصحية 333 في مر افق صحة الأسرة في منطقة المحلة الكبرى ، محافظة الغربية في عام 2018. تم الحصول على مو افقة خطية مستنيرة من كل مشـارك وتم تطبيق استبيان منظم يتضمن ثلاثة أجز اء لتقيميم الخصـائص العامـة للعـلين في مجـال الرعايـة الصحية ، المعرفة و الموقف من سرطان عنق الرحم.

بالإضافة إلى ذلك ، تم إجر اء برنامج للنتقيف الصحي لتحسين معارفهم وموقفه. وتم اجر اء اختبار بعدي لهم بعد 3 أثنهر .

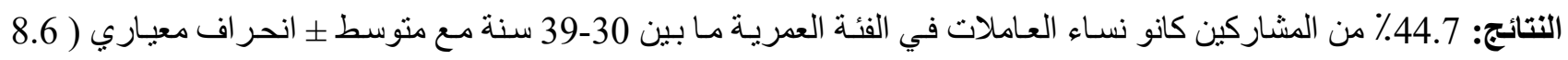
38,51土 كان هناك اختلاف كبير للغاية بين معرفة وموقف العاملين في مجال الرعاية الصحية قبل وبعد التدخل بالبرنامج التعليمي ، حيث كان 20.1 ٪ منهم لديهم درجة معرفة جيدة قبل التدخل لتصبح 43.5 ٪ بعد التدخل. كما كان هنالك تحسن كبير في موقفهم ، حيث ارتفع معدل الاتجاه الايجابي لهم من 40.2\% ليصبح 94.3\% بعد التدخل. الخلاصة: كثفت الدر اسة الحالية أن البرنامج التعليمي المطبق بشـأن سرطان عنق الرحم كان ناجحاً في تعزيز المعرفة وتحسين موقف العاملين في مجـال الرعايـة الصـية تجـاه سرطان عنق الرحم وفحصسه. لذللك نوصـي بمو اصلة بر امج التدريب التعليمي للممرضين وطلاب الطب لزيادة وعيهم بسرطان عنق الرحم. 